JACEK STROJNY

Politechnika Rzeszowska, Polska

\title{
Realizacja innowacyjnej usługi na przykładzie wdrożenia systemu zarządzania projektami
}

\section{Realization of Innovative Services on the Example of the Implementation of the Project Management System}

\begin{abstract}
Streszczenie: Artykuł przedstawia problematykę wprowadzania innowacji na przykładzie wdrożenia systemu zarządzania projektami. Przedstawiono w nim ogólną charakterystykę usługi oraz wybrane doświadczenia autora zebrane podczas realizacji kilkunastu wdrożeń systemów zarządzania projektami w przedsiębiorstwach i samorządach ${ }^{1}$. Aspekty związane z tym zagadnieniem odniesiono do kontekstu zewnętrznego, a więc kształtowania się gospodarki opartej na wiedzy. Podkreślono znaczący wpływ powstającej w niej presji na innowacje na zachowanie się organizacji. Dostosowując się do wymagań otoczenia w coraz większym stopniu muszą się one angażować we wprowadzanie innowacji organizacyjnych.

Jednym z przykładów takiej aktywności jest wprowadzenie orientacji projektowej. Tego typu zmiana wprowadza w przedsiębiorstwie nowe warunki realizacji pracy, dzięki zastosowaniu kompleksowych rozwiązań w zakresie: struktury organizacyjnej, technik zarządzania ludźmi czy technik planowania i controllingu zadań. Organizacja zorientowana projektowo jest bardziej elastyczna, a przez to skuteczna i efektywna. Ponadto lepiej zaspokaja potrzeby klientów oraz innych interesariuszy, co wpływa pozytywnie na zdolności konkurowania.

W Polsce w wielu branżach wprowadzenie orientacji projektowej można wciąż traktować jako innowację o zasięgu branżowym, wpływającą na podniesienie potencjału konkurencyjnego. Wraz z rozpowszechnieniem się tego typu rozwiązań poziom innowacyjności spada, wciąż jednak w odniesieniu do przedsiębiorstwa takie wdrożenie traktować należy jako zmianę radykalną, która zgodnie z podejściem przyjętym w Podręczniku Oslo ma spełniać kryteria innowacji. Wydaje się, że wprowadzenie systemu zarządzania projektami wciąż może być traktowane jako działanie wysoce innowacyjne, m.in. w odniesieniu do polskich instytucji badawczo-rozwojowych.
\end{abstract}

Abstract: The article presents the issues of innovation, providing an example of the implementation of the project management system. Aspects related to this issue were brought to the external context, i.e., the development of a knowledge-based economy. Its significant impact - resulting in pressure on inno-

1 Autor od 2006 r. uczestniczy w przedsięwzięciach reorganizacyjnych związanych z dostosowywaniem organizacji różnego typu do funkcjonowania w formule projektowej lub szerzej - zadaniowej. W latach 2009-2012 był także współwłaścicielem firmy consultingowej specjalizującej się w tego typu wdrożeniach. 
vation - on the behavior of the organization is underlined. Adjusting to the requirements of the environment, companies must be increasingly involved in the implementation of organizational innovations. One of the examples of such activities is an execution of project orientation. This type of change introduces new conditions of work through the use of comprehensive solutions for: organizational structure, HR management techniques or techniques of planning and controlling tasks. Project oriented organization is more flexible, effective and efficient. In addition, it meets the needs of customers and other stakeholders better, which affects positively the ability to compete.

In Poland in many industries the implementation of project orientation can be still treated as innovation on the industry sector scale, affecting the increase of the competitive potential. Along with the spread of this type of solutions, the level of innovation falls; however, for entrepreneurships such implementation should be treated as a radical change, which is to meet the criteria of innovation in accordance with the approach adopted in the Oslo manual. It seems that the implementation of a project management system can still be treated as a highly innovative, especially in the relation to the Polish research and development institutions, among others.

Słowa kluczowe: innowacje organizacyjne, zarządzanie projektami, usługi wdrożeniowe, kapitał ludzki, gospodarka oparta na wiedzy

Key words: organizational innovations, project management, implementation services, human capital, knowledge-based economy

\section{WPROWADZENIE}

Gospodarka oparta na wiedzy to taki sposób organizacji procesów wytwarzania wartości dodanej w systemach gospodarczych, w którym główną determinantą sukcesu (sprawności i efektywności działania) jest dostęp do zasobów niematerialnych, a więc przede wszystkim kompetencji ludzkich. W tak zorientowanej przestrzeni gospodarczej obserwuje się rosnące znaczenie usług, wyrażające się zarówno zmianą struktury zatrudnienia, jak i wytwarzania PKB. Rosnące wymagania względem sprawności działania organizacji, przy jednoczesnej zmianie zewnętrznych warunków funkcjonowania, zwiększają znaczenie przedsięwzięć restrukturyzacyjnych o charakterze innowacji organizacyjnych. Dzięki tego typu zmianom możliwe jest sprawniejsze wprowadzanie nowych rozwiązań w innych obszarach, a więc innowacji procesowych (technologicznych), marketingowych czy wreszcie produktowych.

W niniejszym artykule przedstawiono zagadnienia związane z realizacją usług wdrożeniowych polegających na wprowadzeniu innowacji organizacyjnej dotyczącej reorientacji projektowej przedsiębiorstwa. Efektem takiego działania jest wprowadzenie systemowych rozwiązań, które podnoszą sprawność realizacji zadań poprzez zastosowanie technik pozwalających na odpowiednie ich zaplanowanie oraz controlling wykonywania. Celem artykułu jest omówienie przebiegu takiego wdrożenia wraz z identyfikacją potencjalnych zagrożeń, które mogą wystąpić zarówno w jego trakcie, jak i po uruchomieniu nowego rozwiązania. Ponadto podjęto próbę wskazania, które elementy wdrożenia systemu zarządzania projektami decydują o tym, że można tego typu przedsięwzięcie traktować jako innowację organizacyjną. Jej wpływ na kompetencje zarządcze i międzyludzkie jest szczególnie istotny z punktu widzenia uwarunkowań gospodarki opartej na wiedzy. Ten wpływ również poddano ocenie, 
odwołując się zarówno do literatury przedmiotu, jak i doświadczenia zawodowego autora. Przedstawiając schemat usługi zwrócono także uwagę na możliwość tworzenia nowoczesnej oferty dla przedsiębiorstw przez podmioty badawczo-rozwojowe zajmujące się problematyką zarządzania.

\section{GOSPODARKA OPARTA NA WIEDZY A INNOWACJE ORGANIZACYJNE}

Pojęcia takie jak „gospodarka oparta na wiedzy” czy „innowacje organizacyjne” są ważnymi elementami terminologii wykorzystywanej we współczesnym dyskursie dotyczącym mechanizmów rozwoju czy to gospodarek, czy organizacji. Nie ulega wątpliwości, że zmiany technologiczne i wynikające z nich procesy globalne drastycznie wpływają na specyfikę gospodarowania w każdym z możliwych wymiarów, od mikro, przez mezo-, po makroekonomiczny. W tym kontekście oraz odnosząc się do tytułu niniejszego artykułu warto zastanowić się nad tym, jakie parametry charakteryzują gospodarkę opartą na wiedzy oraz jak one wpływają na zapotrzebowanie na innowacje organizacyjne oraz charakter tego typu przedsięwzięć.

Odnosząc się do pierwszego z wymienionych pojęć należy stwierdzić, że opisuje ono bardzo złożone zjawisko polegające na podnoszeniu znaczenia wiedzy jako zasobu krytycznego dla sprawności procesów gospodarowania. W takiej sytuacji zasoby materialne - majątek rzeczowy, surowce, praca ludzka - stają się wtórnym czynnikiem sukcesu, a sprawność ich wykorzystania zależy od poziomu wiedzy zgromadzonej czy w organizacji, czy w danym systemie gospodarczym. Możliwości zwiększania dobrobytu zależą więc już nie tyle od dostępności zasobów materialnych, co od sprawności procesów wytwarzania i transferu wiedzy.

Rozwój gospodarki opartej na wiedzy wpływa na zmianę sposobu postrzegania człowieka i jego roli w budowaniu fundamentów postępu cywilizacyjnego. Współcześnie w coraz większym stopniu w strategiach rozwojowych zwraca się uwagę na wpływ kapitału ludzkiego (analizowanego zarówno w wymiarze ilościowym, jak i jakościowym) na zdolności konkurowania na rynkach globalnych. W wymiarze systemów gospodarczych znajduje to odzwierciedlenie w strategiach rozwojowych, które ukierunkowane są na budowanie warunków rozwoju niezbędnych kompetencji. W przypadku Polski widoczne jest to zarówno na poziomie długookresowej i średniookresowej strategii kraju, zintegrowanych strategii funkcjonalnych (np. tworzone: Strategia Rozwoju Kapitału Ludzkiego czy Strategia Innowacyjności i Efektywności Gospodarki), a także strategii regionalnych. Na poziomie organizacji mówi się także o rosnącym znaczeniu kultury organizacyjnej, kompetencji pracowników, ich postaw, kreatywności czy zdolności do elastycznego reagowania na zmiany.

Zmiany w sposobach zarządzania rozwojem systemów gospodarczych czy pojedynczych organizacji idą więc $\mathrm{w}$ kierunku uwolnienia potencjału drzemiącego w jednostkach, ale także w relacjach międzyludzkich. Dzięki niemu możliwe jest uruchomienie procesów innowacyjnych, które należy traktować jako podstawowy czynnik rozwoju. To dzięki nim można obserwować postęp zwiększający efektywność gospodarek, ale też znacząco 
zwiększający dobrobyt i jakość życia społeczeństw. Ta presja na ciągłe doskonalenie, oprócz wielu korzystnych efektów, tworzy też wyzwania nie znane do tej pory. Wiążą sie one z coraz większym zaangażowaniem ludzi, przedsiębiorstw i całych gospodarek w proces ciągłego poszukiwania nowych rozwiązań, dzięki którym można lepiej, szybciej, taniej, bardziej skutecznie zaspokajać rosnące potrzeby społeczeństw.

Wytworzona w gospodarce opartej na wiedzy presja na kreatywność i innowacyjność wymusza stosowanie takich metod zarządzania organizacją, które maksymalizują efektywność i skuteczność reakcji na zmiany. Ich wprowadzenie może mieć charakter ewolucyjny i polegać na ciągłym doskonaleniu, lub radykalny, a więc związany z wprowadzeniem całkowicie nowej metody, nie stosowanej dotąd w organizacji. Te dwa podejścia są oczywiście komplementarne. W pierwszym kroku organizacja, która dąży do podniesienia efektywności zarządzania, wprowadza bowiem nowe rozwiązanie, które następnie wymaga stopniowej modyfikacji i doskonalenia aż do momentu, w którym konieczne stanie się wprowadzenie kolejnej innowacji.

Innowacyjną zmianę organizacyjną należy traktować jako działanie, które powinno uwalniać istniejący w organizacji potencjał rozwojowy. Polega ona bowiem na zmianie sposobów funkcjonowania organizacji w taki sposób, że wpływa to pozytywnie na jej konkurencyjność. Rozumiejąc ją w taki właśnie sposób, należy przyjąć, że jest to aktywność poprzedzająca wprowadzenie innego typu innowacji: technologicznych, produktowych czy marketingowych. Wprowadzenie innowacji organizacyjnych to bezpośrednie oddziaływanie na kapitał ludzki danej organizacji. Można więc tutaj mówić zarówno o transferze i wytwarzaniu wiedzy, jak i o jej użyciu do zwiększenia wartości dodanej. Pojawiają się więc tutaj wszystkie elementy procesu zarządzania wiedzą, charakterystyczne dla gospodarki opartej na wiedzy.

Wszystkie podmioty, które dążą do podniesienia konkurencyjności, muszą wprowadzać nowoczesne rozwiązania. Współczesna gospodarka ma jednak charakter sieciowy, oparty na wielu współzależnościach i skomplikowanym systemie relacji. Nowoczesne rozwiązania kooperacyjne (w tym klastrowe), które wpisują się w obraz gospodarki opartej na wiedzy, udrażniają transfer innowacji, a wiec także wiedzy dotyczącej metod zarządzania. Powoduje to sytuację, w której upowszechnienie się pewnych standardów osłabia ich wykorzystanie jako parametrów konkurencyjności na rynku. Dlatego też konieczne staje się poszukiwanie kolejnych rozwiązań, które pozwolą na uzyskanie przynajmniej chwilowej przewagi nad innymi podmiotami.

\section{ORIENTACJA PROJEKTOWA - WYMIARY ORAZ WPEYW}

NA KONKURENCYJNOŚĆ PRZEDSIĘBIORSTW PRZEMYSŁOWYCH I USŁUGOWYCH

Orientacja projektowa to taki sposób organizacji przedsiębiorstwa, w którym znaczna część zadań realizowana jest w formule wyodrębnionych przedsięwzięć, dla których określono: zakres, budżet, harmonogram i odpowiedzialność. Podejście to stosowane jest z powodzeniem w biznesie od połowy XX wieku, a metoda, która opisuje przebieg tego typu 
procesu zarządzania to zarządzanie projektami (Project Management). Wraz z rozwojem cyklu życia metody wzbogaca się ona o kolejne techniki oraz szczegółowe metodyki/wytyczne, opracowywane na podstawie doświadczeń zbieranych w różnych branżach i środowiskach kulturowych. Obecnie w Polsce i na świecie wyróżniają się tzw. metodyki liniowe (PMI, IPMA czy PRINCE2 ${ }^{\circledR}$ ) oraz metodyki zwinne, wywodzące się z manifestu AGILE i adresowane głównie do branży informatycznej.

Szczegółowe rozwiązania organizacyjne w danej organizacji wynikają zarówno z jej specyfiki, jak i z wybranej metodyki/wytycznych. W większości przypadków można mówić jednak o kilku wymiarach orientacji projektowej, które są uniwersalne i powinny być brane pod uwagę w procesie wdrożenia. Należą do nich ${ }^{2}$ :

- kultura projektowa,

- zarządzanie zespołem projektowym,

- zarządzanie strategiczne,

- zarządzanie projektami,

- kompleksowe podejście do zarządzania projektami.

Pierwszy z wymienionych wymiarów orientacji projektowej odnosi się do parametrów, które pozwalają określić na ile tego typu podejście jest potrzebne oraz zakorzenione w zachowaniu się danej organizacji. Warto tutaj po pierwsze zwrócić uwagę na to, jak duża część aktywności jest lub może być realizowana w formule projektowej. Współcześnie, nawet przedsiębiorstwa realizujące produkcję ciągłą w coraz większym stopniu muszą konkurować wykorzystując krótkie serie oraz realizując kompleksowe zlecenia. Dlatego też zarząd powinien być zainteresowany wprowadzeniem systemowego rozwiązania w tym zakresie oraz wspierać osoby odpowiedzialne za projekt. Szczególnie ważne jest to w przypadku przedsięwzięć kluczowych, które w większości przypadków stwarzają także duże ryzyko dla organizacji. Jednym z ważniejszych przejawów istnienia kultury/świadomości projektowej jest wykorzystanie różnego rodzaju instrumentów wspierania procesu zarządzania - a więc procedur, dokumentów oraz narzędzi informatycznych.

Drugi wymiar dotyczy funkcjonowania zespołów projektowych oraz wynikających stąd wyzwań dla systemu personalnego. Pierwszym ważnym zadaniem wynikającym z tego wymiaru jest rozwój kompetencji projektowych. Chodzi tutaj zarówno o system wartości, który powinien ukierunkowywać zachowania się ludzi na zwiększenie efektywności i skuteczności pracy oraz ciągłe doskonalenie się. Konieczne jest także przygotowanie schematu ścieżek zawodowych alternatywnych dla wymiaru liniowego struktury organizacyjnej i obejmujących np. hierarchiczną listę kategorii kierowników projektu. W zależności od posiadanego doświadczenia projektowego osoby mogą dzięki temu liczyć na możliwość zarządzania projektami o odpowiednich parametrach (budżecie, czasie trwania, ryzyku, itd.). Ważne jest także, aby pracownicy widzieli interesującą dla siebie ścieżkę rozwoju, opartą właśnie na uczestniczeniu w projektach. Jednym z elementów wspierających tego typu świadomość jest

\footnotetext{
Kryteria orientacji projektowej organizacji przyjęte w metodyce Project5, opracowanej przez J. Strojnego i K. Witkowskiego na potrzeby analizy i ewaluacji wdrożenia systemów zarządzania projektami w przedsiębiorstwach (przyp. aut.).
} 
system motywacyjny skonstruowany w taki sposób, aby premiować właśnie efektywność i skuteczność pracy w projektach.

W większości przypadków dużym wyzwaniem występującym w ramach omawianego wymiaru orientacji projektowej jest udrożnienie kanałów komunikacyjnych. Projekty, przynajmniej w części są zadaniami, które wymagają współpracy wielu komórek liniowych, przetwarzania różnego rodzaju informacji oraz rozwiązywania zróżnicowanych merytorycznie problemów. Sprawny system komunikacji pozwala upowszechniać niezbędne informacje w sposób selektywny, a więc dostosowany do potrzeb danej grupy odbiorców. Wskazane w poprzednim wymiarze narzędzia informatyczne znacząco podnoszą komfort oraz efektywność tego procesu. Jednym z możliwych rozwiązań jest chociażby publikowanie informacji o projekcie z wykorzystaniem oprogramowania MS SharePoint.

Trzeci wymiar orientacji projektowej dotyczy przeniesienia założeń strategicznych na bieżące decyzje. Sprawność organizacji w średnim i długim okresie zależy od umiejętności koncentracji zasobów na priorytetach. Stąd też ważne jest po pierwsze umiejętne definiowanie strategii, w taki sposób aby zawierała cele możliwe do przełożenia na aktywność bieżącą. Jednym z mechanizmów, które pozwalają na wprowadzenie założeń strategicznych w sposób skoordynowany i skuteczny jest uruchomienie programów. Są to działania, które skupiają projekty rozłożone w czasie, ale logicznie ze sobą powiązane i prowadzące do osiągnięcia celu strategicznego. Dodatkowo ważne jest także optymalizowanie przebiegu bieżącego zarządzania organizacją, a więc całego portfela projektów. Dzięki temu długookresowe cele weryfikowane są pod kątem możliwości ich realizacji w krótkim okresie przy określonych zasobach ludzkich, materialnych i finansowych.

Sprawność działania podnoszona jest także poprzez rozwój kolejnego wymiaru, który dotyczy procesu zarządzania projektem. Ważne jest dostosowanie procedur do specyfiki organizacji oraz przedsięwzięć. Dzięki temu poszczególne fazy projektu, a więc: inicjowanie, definiowanie, planowanie, realizacja i zamykanie mogą przebiegać w taki sposób, aby zapewniać odpowiednią jakość zarządzania. W zależności od wielkości organizacji poziom szczegółowości procedur, a przede wszystkim obowiązki raportowe mogą różnić się od siebie. W małych organizacjach większość uzgodnień i informacji oraz innych działań związanych z zarządzaniem może wykorzystywać kanały nieformalne. W większych podmiotach natomiast konieczne może się okazać sformalizowanie niektórych elementów zarządzania, wprowadzenie dodatkowych raportów związanych z rozliczaniem czasu pracy czy efektów uzyskiwanych w poszczególnych zadaniach projektu.

Ostatni wymiar orientacji projektowej zwraca uwagę na obszary zarządzania, które w sposób szczególny determinują przebieg przedsięwzięcia. Nowoczesne organizacje, dążąc do zwiększenia konkurencyjności powinny wychodzić poza standardową aktywność związaną z planowaniem i controllingiem przedsięwzięcia, stosując bardziej wyrafinowane techniki. Bardzo istotne współcześnie jest zarządzanie relacjami z interesariuszami. Tego typu kategoria podmiotów obejmuje nie tylko klientów i dostawców, ale także inne podmioty, które mogą być determinowane lub zainteresowane przebiegiem projektu. Wprowadzenie analizy interesariuszy do katalogu działań realizowanych w trakcie przygotowywania i realizacji projektu świadczy o wysokim poziomie orientacji projektowej. Podobnie zresztą rzecz 
się ma z zarządzaniem ryzykiem czy jakością w projektach. Te aspekty współcześnie mogą decydować o sukcesie projektu, a długofalowo także o pozycji rynkowej organizacji.

Warto także rozważać włączenie do praktyki organizacji niektórych elementów nowoczesnego zarządzania finansami projektu, zwłaszcza w zakresie związanym z analizą płynności finansowej oraz analizy wartości wypracowanej. Dzięki temu zarówno kierownik projektu, służby controllingowe, jak i zarząd uzyskuje szerokie spektrum informacji zarządczej decydującej o kondycji finansowej organizacji.

Osobnym elementem, który jest analizowany w ramach ostatniego wymiaru, jest system zarządzania dokumentacją. W praktyce powinien on stanowić składową część systemu zarządzania projektami. Należy zadbać o zgodność wizualną, a przede wszystkim merytoryczną poszczególnych dokumentów obsługujących dany projekt.

\section{USŁUGA WDROŻENIA SYSTEMU ZARZĄDZANIA PROJEKTAMI}

JAKO PRZYKŁAD INNOWACJI ORGANIZACYJNEJ

Niniejszy artykuł poświęcono problematyce wdrożenia orientacji projektowej w organizacji, jako metody zarządzania, która pozwala stworzyć standard reakcji na zmiany warunków poprzez zwiększenie elastyczności i skuteczności planowania i realizacji zadań. Autor stoi na stanowisku, że wprowadzenie tego typu systemowego rozwiązania może być traktowane jako przykład innowacji organizacyjnej. W wielu branżach, zwłaszcza w warunkach polskich, stanowi ono wciąż parametr zwiększający konkurencyjność danej organiza$\mathrm{cji}^{3}$. Może z tego powodu być traktowane jako innowacja na skalę branży. Oczywiście wraz z upowszechnianiem się tego typu podejścia występuje transfer wiedzy, który powoduje, że poziom innowacyjności tego typu przedsięwzięcia spada, przekształcając orientację projektową w kompetencję stanowiącą barierę wejścia. W takiej sytuacji wykorzystanie podejścia projektowego jest konieczne do przetrwania na rynku, jako element standardowego przebiegu procesu zarządzania. Przyjmując jednak podejście wynikające z Podręcznika Oslo, nawet wówczas można mówić o innowacji, ponieważ wdrożenie orientacji projektowej stanowi istotną zmianę dla organizacji.

Warto zauważyć, że w coraz większym stopniu (również w Polsce) wprowadzanie innowacji organizacyjnych przebiega z wykorzystaniem outsourcingu. Udział wyspecjalizowanych firm consultingowych, dysponujących doświadczeniem, narzędziami oraz wypracowaną metodyką realizacji innowacji, zmniejsza ryzyko niepowodzenia. Dana organizacja wprowadzając nowe rozwiązania, zwłaszcza systemowe, w dużym stopniu zmienia zasady realizacji procesu pracy, wykorzystania zasobów (materiałowych czy usług obcych), wynagradzania, itd. Są to na tyle istotne zmiany, że błędnie przygotowane mogą skutkować problemami nie tylko w trakcie wdrożenia, ale także po jego zakończeniu. Kompleksowość

\footnotetext{
W Polsce nie prowadzono do tej pory kompleksowych badań na temat orientacji projektowej organizacji. Jednym z nielicznych przykładów może być Badanie dojrzałości projektowej firm z północnej Polski przeprowadzone przez PMI. Opinia wyrażona w artykule ma więc charakter subiektywnej oceny sytuacji przez autora i bazuje na jego doświadczeniu w pracy wdrożeniowej.
} 
zmiany powoduje, że organizacja, realizując ją samodzielnie, może nie poradzić sobie ze złożonymi i licznymi problemami, które stanowią dla niej nowe wyzwania. Podmiot przeprowadzający podobne wdrożenie w kolejnej organizacji z wyprzedzeniem przeciwdziała powstaniu niektórych problemów, a gdy wystąpią często dysponuje już skutecznymi schematami reakcji.

Przyjmując przedstawiony schemat relacji pomiędzy firmą produkcyjną lub usługową, wprowadzającą innowację organizacyjną, a wyspecjalizowanym podmiotem wykonującym na zlecenie usługę wdrożenia, omówiono schemat takiej współpracy. Wykorzystano tutaj przykład dotyczący wdrożenia systemu zarządzania projektami, omówiony na podstawie autorskiej metodyki opracowanej przez J. Strojnego i K. Witkowskiego, oferowanej pod nazwą Project5. Ogólny zakres usługi obejmuje działania, składające się na pięć podstawowych modułów wdrożenia:

- analityczny,

- wdrożeniowy,

- ewaluacyjny,

- controllingowy,

- consultingowy.

Pierwszy z wymienionych modułów ma charakter analityczny. Wiąże się on z określeniem parametrów startowych dla wdrożenia w danej organizacji. Czynności mają więc charakter analityczny, zarówno w odniesieniu do merytorycznego zakresu wdrożenia, jak i elementów otoczenia wewnętrznego organizacji. Do podstawowych czynności badawczych należą:

- badanie postaw pracowników wobec zmiany,

- analiza organizacji pracy,

- analiza przebiegu procesów,

- analiza istniejących systemów zarządzania,

- analiza uwarunkowań prawnych zmiany,

- analiza uwarunkowań finansowych.

Efektem końcowym prac w ramach etapu przedwdrożeniowego jest raport lub raporty zawierające efekty przeprowadzonych analiz. Należy szczególnie zwrócić uwagę na to, czy pracownicy są gotowi do zmian i nie będą źródłem oporu. Ten aspekt jest jednym z najważniejszych z punktu widzenia przebiegu innowacji organizacyjnej. Kolejne obszary badania dotyczą sprawności procesów zarówno w wymiarze struktury organizacyjnej, jak i stosowanych procedur. Na ich przebieg mogą wpływać stosowane już w organizacji systemy zarządzania, których obecność należy wziąć pod uwagę podczas przygotowywania założeń wdrożenia. Podobnie rzecz się ma w przypadku różnego rodzaju uwarunkowań prawnych (w szczególności dotyczących relacji pracodawca-pracownik).

$\mathrm{Na}$ podstawie przeprowadzonej analizy przygotowuje się plan wdrożenia. W standardowym wdrożeniu systemu zarządzania projektami powinien on zawierać czynności, obejmujące:

- mapowanie procesów,

- wdrożenie nowej organizacji, 
- wdrożenie nowego systemu motywacyjnego,

- wdrożenie nowych zasad sprawozdawczości finansowej,

- wdrożenie systemu informatycznego.

Punktem wyjścia w orientacji projektowej jest stworzenie mapy procesów, na podstawie której identyfikuje się te zadania, określając ich specyfikę (projekt lub proces). Tworzy się w ten sposób struktura podziału pracy dla całej organizacji, na podstawie której wyznacza się odpowiedzialność za zadania, a także założenia przygotowania alokacji zasobów, harmonogramów czy budżetów. Ponadto możliwe jest wyodrębnienie typów projektów, co ułatwia ich podział i organizację w postaci wyodrębnionych subportfeli.

Ważnym punktem wdrożenia jest zmiana struktury organizacyjnej. Podstawowym rozwiązaniem, które w praktyce sprawdza się w organizacjach zorientowanych projektowo jest tzw. struktura macierzowa. Pozwala ona na wyodrębnienie dwóch wymiarów organizacji: liniowego, zajmującego się realizacją procesów oraz tymczasowego, zajmującego się realizacją projektów. Wprowadzenie zespołów projektów, a niekiedy także programów oraz odpowiadających im kategorii stanowiskowych (kierownik projektu lub programu czy członek zespołu projektu lub programu) pozwala czytelnie określić odpowiedzialność za zadania oraz oddzielić zarządzanie projektami od zarządzania procesami. Widocznym wyrazem wprowadzenia orientacji zadaniowej jest też utworzenie:

- komórki PMO (Project Management Office),

- stanowiska pełnomocnika ds. systemu zarządzania projektami,

- stanowiska kierownika portfela.

Wymienione wyżej elementy struktury organizacyjnej mają charakter liniowy, a ich utworzenie ma na celu wsparcie kierowników projektu. Komórka PMO, prócz ról controllingowych ma przede wszystkim za zadanie rozwijać kompetencje projektowe i pomagać w realizacji projektów zarówno pod względem organizacji źródeł finansowania, wykorzystywania procedur, jak i rozwiązywania problemów. Szczególną rolę odgrywają tutaj zarówno pełnomocnik, jak i kierownik portfela. Pierwszy z nich dba o aktualność systemu zarządzania projektami, optymalizując procedury, modyfikując dokumenty czy weryfikując skuteczność stosowanych technik. Natomiast drugie stanowisko powinno się skupiać głównie na ocenie wzajemnego oddziaływania na siebie przedsięwzięć realizowanych jednocześnie w ramach danego portfela.

Przygotowanie i uruchomienie nowych rozwiązań w początkowej fazie zazwyczaj obniża efektywność pracy i powoduje przejściowe kłopoty z koordynacją zadań realizowanych na bieżąco. Prawidłowa ocena innowacji powinna więc zostać odsunięta w czasie o kilka miesięcy od zakończenia prac wdrożeniowych. Pracownicy mają dzięki temu możliwość zmiany przyzwyczajeń i wypracowania sposobów pracy zapewniających docelowy poziom efektywności w nowych warunkach. W ramach ewaluacji wdrożenia warto podjąć następujące działania:

- ocena poziomu zadowolenia pracowników po wdrożeniu,

- ocena zgodności rzeczywistych działań z planowanym przebiegiem procesów,

- ocena sprawności organizacyjnej w oparciu o wywiady z kierownictwem,

- ocena sprawności systemu motywacyjnego, 
- ocena sprawności gospodarki zasobami,

- ocena sprawności controllingu operacyjnego,

- ocena sprawności systemu informatycznego.

Jednym z elementów, które warto zweryfikować jest ocena zadowolenia pracowników po wdrożeniu. Zmęczenie zmianą i trudności w dostosowaniu się do nowych zasad powodują często niechęć i bierny opór, który może spowalniać wychodzenie z niższej wydajności pracy. Rozpoznanie tego stanu oraz analiza przyczyn może doprowadzić do identyfikacji obszarów wymagających korekty. Szczególnie owocne mogą być tutaj także wywiady z kierownictwem. Szczególnie należy zwrócić uwagę na sprawność realizacji zadań, gospodarki zasobami czy controllingu. Jeśli w ramach wdrożenia wprowadzono system informatyczny, często pojawiają się problemy z obsługą jego funkcjonalności. Dotyczy to szczególnie produktów dedykowanych, które przechodzą zazwyczaj przez „choroby wieku dziecięcego”.

Bardzo ważną kwestią jest motywacja do pracy, która reaguje zarówno na sam przebieg wdrożenia, jak i na ewentualnie wprowadzone zmiany w systemie motywowania. W trakcie ewaluacji należy zweryfikować także tę kwestię. Ważne przy tym jest, aby sam proces pozyskiwania tego typu informacji był odpowiednio przygotowany i nie wywoływał napięć bądź eskalacji niezadowolenia.

Tradycyjny układ działań związanych z realizacją wdrożenia kończy się na wymienionych wyżej trzech modułach. W przedstawionej w niniejszym artykule propozycji konstrukcji usługi realizowanej przez podmiot zewnętrzny można przewidzieć jeszcze dodatkowe działania, wspierające wprowadzoną innowację organizacyjną. Wpisują się one w powszechnie obserwowany trend związany z outsourcingiem zadań, co zwiększa prawdopodobieństwo popytu również na zadania polegające na przejęciu controllingu projektów oraz consultingu powdrożeniowego. Pierwszy z wymienionych modułów polega na realizacji przez podmiot zewnętrzny obsługi projektów poprzez stworzenie zewnętrznego PMO. Podstawowe zalety takiego rozwiązania wynikają z utrzymania ciągłej dbałości o jakość controllingu operacyjnego projektów. W wielu organizacjach bieżące problemy powodują stopniowe odchodzenie od tego typu aktywności ze względu na ograniczoność zasobów. Dodatkowo, dzięki wykorzystaniu specjalistów z dziedziny zarządzania projektami, firma zewnętrzna może sprawniej i skuteczniej informować o zagrożeniach występujących w trakcie realizacji projektu. Podstawową barierą natomiast jest obawa związana z wyciekiem poufnych dla danej firmy informacji dotyczących stanu projektów czy ogólnej kondycji.

Warto podkreślić, że system zarządzania projektami, podobnie jak wszystkie innowacyjne zmiany, wymaga ciągłego doskonalenia. Te zadania realizuje zazwyczaj powołany pełnomocnik. Mogą one jednak z powodzeniem stanowić część składową usługi zewnętrznej. Cykliczny audyt zgodności wykonywany przez zewnętrzną firmę daje większe prawdopodobieństwo obiektywizmu oraz (co chyba ważniejsze) wymusza zachowanie interwału audytu, zapewniającego prawidłowe funkcjonowanie systemu. Dzięki takiej okresowej ocenie dochodzi bowiem do identyfikacji tych obszarów, w których bieżąca sytuacja organizacji wymusza modyfikację rozwiązań systemowych. 


\section{ZAKOŃCZENIE}

Współczesna gospodarka intensyfikuje procesy tworzenia i transferu wiedzy. Przedstawiony przykład usługi consultingowej wpisuje się w jej charakter z kilku powodów:

- przedstawienie schematu wdrożenia innowacji organizacyjnej, która jest szczególnie istotnym rodzajem aktywności w gospodarce opartej na wiedzy,

- określenie jednego z obszarów rozwoju sieciowych relacji opartych na outsourcingu,

- przedstawienie schematu usługi (metodyka Project5) na styku szkolnictwa wyższego i realnej gospodarki.

Pierwszy z wymienionych powodów przedstawiono szczegółowo we wcześniejszych punktach artykułu. Na uwagę w podsumowaniu zasługują natomiast szczególnie pozostałe dwa aspekty. Wraz z rozwojem gospodarki opartej na wiedzy w różnego rodzaju dokumentach programowych (na poziomie UE, krajowym czy regionalnym) podkreśla się potrzebę wypracowania mechanizmów pozwalających na skuteczną współpracę między środowiskiem akademickim a przedsiębiorstwami. Kryje się w nich potencjał pozwalający na zwiększenie innowacyjności, a przez to także konkurencyjności zarówno pojedynczych podmiotów, jak i całych systemów gospodarczych. Dużą rolę w tym procesie mogą odgrywać uczelnie umiejętnie i efektywnie współpracujące z realną gospodarką. Zarówno w Polsce, jak i w innych krajach Europy kontynentalnej, w których wciąż dominuje jednak humboltowski model uczelni, przekształcenie ich w tzw. uniwersytet przedsiębiorczy napotyka jednak wciąż na bariery. W Polsce, wśród najważniejszych zdaniem autora, można wymienić:

- zbyt małą aplikowalność wyników badań naukowych (zwłaszcza w naukach społecznych) do realnych procesów gospodarczych,

- trudności w rozpoznawaniu zapotrzebowania na określone kierunki badań,

- brak doświadczenia znacznej części pracowników naukowych w realizacji usług na rzecz gospodarki,

- niedostosowanie struktury organizacyjnej oraz systemu wynagrodzeń w uczelniach do działań związanych z pozyskiwaniem i obsługą zleceń komercyjnych.

Przekształcenie uczelni w instytucje przedsiębiorcze może otworzyć nowy, niezwykle istotny rynek dla usług związanych z reorganizacją tego typu instytucji, w tym z wdrażaniem systemów zarządzania projektami. Wdrożenie tego typu innowacji może być skuteczną drogą do intensyfikacji przedsięwzięć o charakterze spin off/spin out. Warto na tym przykładzie zwrócić uwagę, że potencjał współpracy kryje się nie tylko w jednostkach akademickich zajmujących się naukami technicznymi. Znaczny zasób wiedzy, potencjalnie użytecznej dla przedsiębiorstw, mają także ośrodki prowadzące kształcenie i badania w zakresie nauk społecznych, w tym zarządzania. Zmieniająca się sytuacja rynkowa, rozwój metod opartych na outsourcingu oraz wynikające stąd zapotrzebowanie na usługi doradcze powinny stanowić impuls do uruchomienia inicjatyw indywidualnych, ale przede wszystkim także zmiany o charakterze systemowym, związane ze sposobem zarządzania uczelnią. Jedną z podstawowych innowacji organizacyjnych, sprzyjających uruchomieniu procesów komercjalizacji jest właśnie wdrożenie orientacji zadaniowej. 


\section{Literatura / References}

Dałkowski, B., Staśko, L., Zalewski, M. (red.). (2009). Polskie Wytyczne Kompetencji IPMA. Gdańsk: Stowarzyszenie Project Management Polska.

Ministerstwo Gospodarki (2010). Ewolucja sektora ustug w Polsce w latach 1995-2008. Warszawa.

Frame, J.D. (2001). Zarządzanie projektami w organizacjach. Warszawa: WIG-PRESS.

Francik, A. (2003). Sterowanie procesami innowacyjnymi w organizacji. Kraków: Wydawnictwo AE w Krakowie.

Kisielnicki, J. i in. (red.) (2008). Zarzadzanie projektami inwestycyjnymi-aktualne problemy i metody. Gdańsk: Stowarzyszenie Project Management Polska.

Kisielnicki, J. (red.) (2009). Project Management w czasach kryzysu. Gdańsk: Stowarzyszenie Project Management Polska.

Lewis, J.P. (2005). Podstawy zarzadzania projektami. Gliwice: Helion.

Lock, D. (2009). Zarządzanie projektami. Warszawa: PWE.

Matusiak, K.B. (red.) (2011). Innowacje i transfer technologii. Warszawa: PARP.

Niedbała, B. (2008). Controlling w przedsiębiorstwie zarządzanym przez projekty. Kraków: Wolters Kluwer.

Project Management Institute (2008). PMBok Guide 4th Edition. USA.

OECD/European Communites (2008). Podręcznik Oslo. Warszawa.

TSO (2010). PRINCE2 ${ }^{\text {TM }}$ - Skuteczne zarzadzania projektami. GB.

Urbanowska-Sojkin, E., Banaszyk, P., Witczak, H. (2004). Zarządzanie strategiczne przedsiębiorstwem. Warszawa: PWE.

Jacek Strojny, dr, Politechnika Rzeszowska, Wydział Zarządzania.

Autor jest pracownikiem akademickim Wydziału Zarządzania Politechniki Rzeszowskiej. Specjalizuje się w problematyce reorganizacji przedsiębiorstw, w tym wdrażaniu systemowych rozwiązań zarządczych opartych na orientacji projektowej/zadaniowej. Współpracuje z przedsiębiorstwami i instytucjami publicznym, prowadząc szkolenia i wdrożenia m.in. systemów zarządzania projektami, systemów wynagrodzeń czy nowoczesnych, opartych na zarządzaniu przez cele metod zarządzania strategicznego.

Jacek Strojny, Ph.D., Rzeszow University of Technology, Faculty of Management.

The author is an academic employee of the Faculty of Management at Rzeszow University of Technology. He specializes in issues of company reorganization, including implementation of the management systems based on the project/task orientation. He also works with companies and public institutions, running trainings and implementation of project management systems, payroll systems and modern, based on management by objectives methods of strategic management.

adres/address: Politechnika Rzeszowska,

al. Powstańców Warszawy 12, 35-959 Rzeszów, Polska

e-mail: jstrojny@prz.edu.pl 